\title{
Associate Editors/Corédacteurs
}

\section{Prof. Martin Beland}

Professeur de sylviculture et ecologie foresterie, Universite de Moncton, Campus d'Edmunston

\section{Dr. Ryan Bullock}

Asst. Professor, Environmental Studies and Sciences and Centre for Forest Interdisciplinary Research, University of Winnipeg

\section{Dr. James M. Buttle}

Professor of Geography, Trent University

Dr. Jiaxin Chen

Mitigation and Adaptation Research Scientist, Ontario Forest Research Institute, Ministry of Natural Resources and Forestry

\section{Dr. Verena C. Griess}

Asst. Professor of Forest Management, Faculty of Forestry, University of British Columbia

\section{Dr. Ron Hall}

Emeritus Scientist, Remote Sensing Inventory Specialist, Northern

Forestry Centre, Natural Resources Canada

\section{Dr. Andrew Kenney}

Emeritus Professor, Urban Forestry, Agroforestry and Tropical Forestry, University of Toronto

\section{Dr. Maureen Kershaw}

Science Coordinator, Science and Research Branch, Ontario Ministry of Natural Resources and Forestry, Sault Ste. Marie

\section{Dr. Anil R. Kizha}

Asst. Professor of Forest Operations, School of Forest Resources, University of Maine
Dr. Van Lantz

Dean, Faculty of Forestry and Environmental Management, University of New Brunswick

\section{Dr. Vic Leiffers}

Faculty of Agricultural Life and Environmental Sciences, University of Alberta

\section{Dr. Valerie LeMay}

Professor of Forest Biometrics and Measurements, Dept. of Forest Resources Management, University of British Columbia

\section{Professor Martin Luckert}

Resource Economics and Environmental Sociology, University of Alberta

\section{Dr. Rongzhu Man}

Research Scientist, Ontario Forest Research Institute, Ontario Ministry of Natural Resources and Forestry

Dr. Peter Marshall

Professor and Associate Dean, Faculty of Forestry, University of British Columbia

\section{Professor David L. Martell}

Fire and Forest Management Systems, Faculty of Forestry, University of

Toronto

\section{Dr. Keith M. McClain}

National Pine Beetle Ecology Program Leader, Foothills Research Institute

\section{Dr. Rory L. Mclntosh}

Provincial Forest Entomologist and Pathologist, Forest Service Branch, Ministry of Environment, Prince Albert, Saskatchewan
Dr. Margaret Penner

Forest Analysis Ltd., Huntsville, Ontario

Dr. Jim Richardson

Poplar and Willow Council of Canada, Ottawa

\section{Ms. Ngaire Roubal}

Forest Policy Analyst, Ontario Ministry of Natural Resources and Forestry

\section{Professor Jean-Claude Ruel}

Professeur titulaire et directeur du départment des sciences du bois et de la forêt, Université Laval

\section{Professor Michel Soucy}

Harvesting and Forest Economics

University of Moncton

\section{Dr. Michael Stoehr}

A/Manager, Forest Genetics, Forests, Lands and Natural Resource Operations, Government of British Columbia

\section{Dr. Adam Wellstead}

Assistant Professor, Department of Environmental and Energy Policy, Michigan Technological University

\section{Dr. Stephen Wyatt}

Professeur adjoin en aspects sociaux et politques de la foresterie, Faculté de foresterie, Université de Moncton

\section{Dr. Weimin Xi}

Professor, Dept. of Biological and Health Science, Texas $A$ \& $M$ University, Kingsville, Texas 